\title{
A PROPOSAL FOR ACCEPTING PONTASTACUS AS A GENUS OF EUROPEAN CRAYFISH WITHIN THE FAMILY ASTACIDAE BASED ON A REVISION OF THE WEST AND EAST EUROPEAN TAXONOMIC LITERATURE
}

\author{
P. ŚMIETANA (1), H. K. SCHULZ (2), S. KESZKA (3), R. SCHULZ (2)
}

(1) Department of Ecology, University of Szczecin, Poland.

E-Mail: leptosp@univ.szczecin.pl

(2) Institute for Environmental Sciences, University Koblenz-Landau, Landau, Germany.

E-Mail: R.Schulz@uni-landau.de

(3) Department of Fish Systematics, Agriculture University of Szczecin, Poland.

E-Mail: keszka@fish.ar.szczecin.pl

Reçu le 16 juin 2005

Accepté le 20 janvier 2006

Received June 16, 2005

Accepted January 20, 2006

\begin{abstract}
The taxonomic classification of European crayfish is neither fully examined nor generally accepted as a unifying scheme. At present, one of the most obvious differences exists between astacologists from Western and Eastern Europe. In the present paper, an analysis of the information published on the systematics of European crayfish over the last decades was conducted against the background of own observations on features with importance for the systematics of narrow-clawed crayfish (Astacus (Pontastacus) leptodactylus) from Poland. The objective of this analysis was to standardize the nomenclature of European crayfish at the level of genera. The presented proposal for a taxonomy recognizes three genera within the family Astacidae in Europe: Austropotamobius, Astacus, and Pontastacus. The main (morphological, zoogeographical and ecological) criteria for considering the genus Pontastacus a separate genus are of a discriminatory strength similar to the widely accepted criteria for the separation of the genus Austropotamobius. Further studies on the taxonomy and ecology of crayfish from eastern Europe using modern techniques such as molecular genetics are strongly recommended.
\end{abstract}

Key-words: Astacidae, Astacus, Austropotamobius, morphology, Pontastacus, taxonomy.

PROPOSITION POUR ACCEPTER PONTASTACUS EN TANT QUE GENRE D'ÉCREVISSE EUROPÉENNE DE LA FAMILLE DES ASTACIDÉS, SUR LA BASE D'UNE REVUE BIBLIOGRAPHIQUE DE LA TAXONOMIE EST ET OUEST EUROPÉENNE

\section{RÉSUMÉ}

A ce jour, la taxonomie des écrevisses européennes n'a jamais été réellement examinée en détail et aucun consensus existe. Les avis sur leur classification divergent dans la communauté scientifique, notamment entre les astacologistes de l'Ouest de l'Europe et ceux de l'Est. 
Ce travail repose d'une part sur l'analyse des données contenues dans les publications des dernières décennies sur la systématique des écrevisses européennes, et d'autre part sur nos observations morphologiques. L'objectif de cette analyse est d'harmoniser la nomenclature générique des écrevisses européennes. Trois genres d'Astacidae sont ici reconnus en Europe: Austropotamobius, Astacus et Pontastacus. Les principaux critères (morphologiques, zoogéographiques et écologiques) permettant de considérer séparément le genre Pontastacus sont d'un niveau discriminant similaire à celui largement accepté pour la séparation du genre Austropotamobius.

De nouvelles recherches sont nécessaires sur la taxinomie et l'écologie des écrevisses dans l'Est de l'Europe, et l'utilisation de techniques modernes telles que la génétique moléculaire est vivement recommandée.

Mots-clés: Astacidae, Astacus, Austropotamobius, morphologie, Pontastacus, taxonomie.

\section{INTRODUCTION}

The classification of the European freshwater crayfish belonging to the family Astacidae is still a matter of scientific discussion. Considering the increasing number of papers on astacology, the inconsistent terminology becomes a major problem also for those scientists who are not directly involved in taxonomic subjects. In particular, the current situation is difficult for scientists who perform research on the crayfish species complex Astacus (Pontastacus) leptodactylus. Despite different attempts to unify the approaches (HOLDICH, 1992; HOLDICH and GHERARDI, 1999), the differences in the terminology used are still obvious. Differences in the nomenclature in Europe force some scientists even to publish papers or present data using different names for the same species. For example (MIKOUIZA et al., 1998 unpublished abstract) wrote about Astacus leptodactylus eichwaldi and Astacus pachypus. In another publication, these authors named the same species Pontastacus leptodactylus eichwaldi and Caspiastacus pachypus (SOKOLSKY et al., 1999). Similar examples can be found when comparing publications of MASTYŃSKI and ANDRZEJEWSKI, (2001a); MASTYŃSKI and ANDRZEJEWSKI (2001b) or BELYAEVA and CHERKASHINA, (1998 unpublished abstract) and CHERKASHINA et al. (1999) or ŚMIETANA (1998; 1999) and ŚMIETANA (2001). Many of these authors, however, admit that taxonomy of the Astacus (Pontastacus) leptodactylus complex is still in a state of uncertainty.

In order to harmonize the systematic nomenclature, we propose the application of a revised taxonomy based on the latest work done on this subject. This should allow for a broad acceptance by the majority of astacologists in Europe. We limit the suggested taxonomic modifications to the genus level as a first step towards an increased clarification. It is important to note that we understand this paper not as a revision at the genus level, which we expect to be accepted and used immediately by the scientific community. We rather see this paper as a way of stimulating a further discussion process on the genus taxonomy within the European members of the family Astacidae. Furthermore, we would like to encourage scientists to consider the use of Pontastacus at genus level in order to provide more morphological and genetic information specifically from eastern European samples, which will in the end help to establish a genus definition of European Astacidae based on scientific facts.

The taxonomy of European crayfish at the species level is also still in the process of change and development. The separation of new species is still ongoing as exemplified by the growing interest in the Austropotamobius pallipes complex. New studies resulted in the proposal to distinguish four subspecies of Austropotamobius italicus found in Italy ZACCARA et al. (2005) and the description of Austropotamobius berndhauseri by BOTT (1972) and LARGIADĖR et al. (2000), which was discussed by GRANDJEAN et al. (2002) and recently by TRONTELJ et al. (2005). These papers demonstrated the advantage of 
using genetic markers for the categorization of species or subspecies and the revision of the traditionally accepted taxonomic status, and phylogeny. Similar approaches are still needed for East European crayfish species belonging to the family Astacidae and still need to be applied at the genus level, if feasible.

The relatively large interest in Austropotamobius seemed to have induced the commonly accepted agreement for the separation of this genus from the genus Astacus (TAYLOR, 2002). However, the opposite situation seems to be true for the Astacus (Pontastacus) leptodactylus complex. The relative low number or even the lack of recent papers on the taxonomy and genetics of the Astacus (Pontastacus) leptodactylus complex seems to result in the fact that the problems of its taxonomy are neglected or only considered with a large delay.

One of the main reasons for this is probably that there is enormous morphological variations amongst Eurasian populations of Astacus (Pontastacus) leptodactylus which together with its broad distribution, often in regions where access is difficult, make a scientific approach very difficult. Additionally, in most countries in Western Europe, where Astacus (Pontastacus) leptodactylus has been introduced in the past, there is hardly any information as to which and how many different populations were used for stocking. The large number of described forms within the Astacus (Pontastacus) leptodactylus complex as natios, subspecies and species illustrates the problem of lack of basic research on its taxonomy.

This paper should therefore be regarded as a further step to clarify the genus taxonomy within the European Astacidae. Our main point is to suggest the option of accepting Pontastacus as a genus for specimens belonging to the so far only very loosely defined complex Astacus (Pontastacus) leptodacylus. We base our approach on data taken from the literature on taxonomy of European Astacidae. However, we do not attempt to give a full review of this very complex issue. We rather focus on the comparison of scientific approaches from Eastern and Western Europe as this is in our view an approach that has been largely neglected so far. Then we give some details on why we believe that Pontastacus should be considered a full genus within the European species, being aware that this paper cannot be regarded as a concise taxonomic revision. It should stimulate a discussion about the possibility of adding Pontastacus on a genus level in the European Astacidae taxonomy.

\section{RESULTS AND DISCUSSION}

\section{Literature review with an emphasis on regional differences in the approach}

The most important general papers on the taxonomy of Astacidae published over the last several decades are compiled in Table I. Some authors made several contributions, in which case we have tried to summarize their final conclusions in the present paper in order to avoid going into great detail about assumptions that were later revised or modified even by the same author. The proposals of BOTT (1950) can be considered as a first attempt to classify European crayfish. As in his later paper (BOTT, 1972), his studies were based on morphological features, considering also phylogenetic and zoogeographical aspects. BOTT's work strongly influenced other taxonomists in Europe, such as KARAMAN (1962; 1963), BRODSKI (1981; 1983), ALBRECHT $(1982 ; 1983)$ and STAROBOGATOV (1995). The classification at the level of genera and subgenera is similar in BOTT and in KARAMAN. They used the following distinguishable morphological criteria for the genus Austropotamobius: only one pair of postorbital ridges, merus of maxilliped 3 (with a varying number of spines) and total body length (less than $8 \mathrm{~cm}$ ). For the genus Astacus, only one morphological criterion (two pairs of postorbital ridges) was actually mentioned apart from a larger body size. For distinguishing the two subgenera Astacus and Pontastacus, the shape of the rostrum, the epistome, the pleura of the abdominal somites and the talon were used as criteria. 


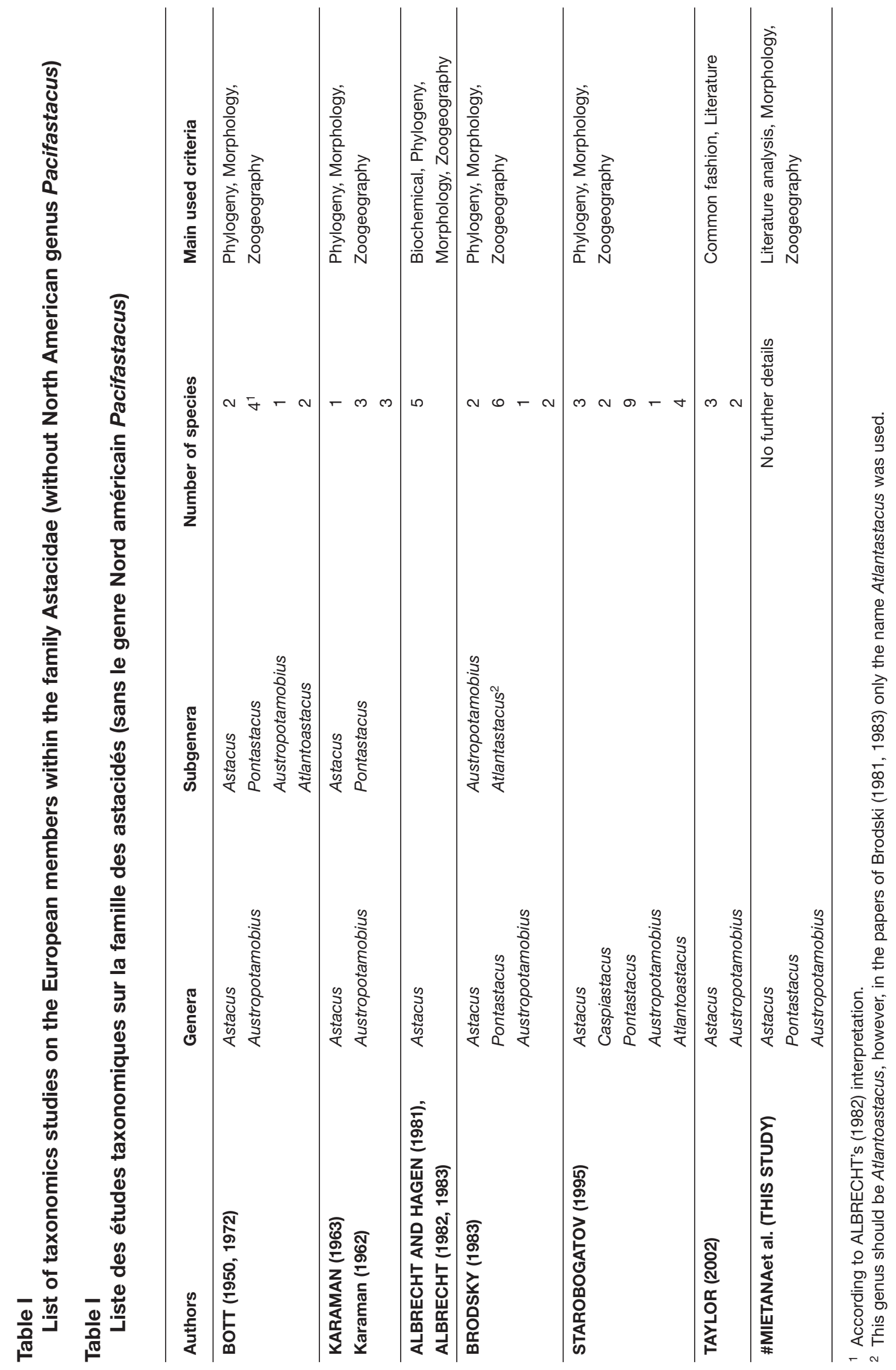


BRODSKI (1981) as well as BOTT (1950; 1972) and KARAMAN (1962) also described the number of postorbital ridges and the body size as separating criteria for Austropotamobius. Additionally, BRODSKI (1981; 1983) hypothesized the usefulness of features such as number of chromosomes for taxonomical classifications at the genus level. It was documented in an earlier study by PROWAZEK (1902), that the number of chromosomes found in Astacus $(4 n=116)$ is less than half the number found in Pontastacus $(8 n=368)$ (SILVER and CUKERZIS, 1964). BRODSKI's proposal to separate a genus Pontastacus resulted also from his assumptions on the phylogeny of the European crayfish with Austropotamobius as the oldest genus and Pontastacus as the youngest. He tried to support the separation of the Austropotamobius genus with the theory that crayfish from this genus probably have $2 \mathrm{n}$ chromosomes. However, the number of chromosomes in Austropotamobius has not yet been examined and therefore this theory has been refused as a taxonomic criterion.

In his earlier paper, BRODSKI (1981) described in detail the differences between the genera Astacus and Pontastacus. According to his description, the genus Pontastacus is characterized by a long grooved rostrum with margins covered with spines and a median carina with spines along the whole length, which is interrupted in front of the eyes. Astacus has a flat rostrum narrowing towards the front with a continuous median carina. Pontastacus has two pairs of equally developed postorbital ridges (postorbital tubercles) as compared with one well-developed postorbital ridge in Astacus. Other separating morphological characters mentioned by BRODSKI (1981) were the pleura of the abdomen inequilaterally pointed with a spinule in Pontastacus and equilateral rounded and unarmed (without spines) in Astacus. The two groups also differ by the shape of the chelae and carapace. Pontastacus has chelae with narrow digits without hollow and conical tubercles at the inner blade of the immovable finger. The carapace is thin covered with tiny spines on the sides with two large ones at the back of the cervical groove. In contrast, Astacus has chelae with hollow and conical tubercles whereas the carapace is smooth and hard. BRODSKI (1981) mentioned a well-developed ventral process (talon) of pleopod 2 in males as another typical criterion for Pontastacus. However, specimens of Pontastacus pachypus show characters of both groups and therefore cannot be simply assigned to one of the genera using the above-mentioned features (BRODSKI, 1983).

ALBRECHT and VON HAGEN (1981) and ALBRECHT (1982; 1983) recognize only one genus Astacus within the family Astacidae with no subgenera and only five species. Within the genus Astacus, ALBRECHT $(1982 ; 1983)$ arranged $A$. torrentium and $A$. pallipes in one clade, forming a sister group to the clade of $A$. leptodactylus and $A$. pachypus. The authors of the present paper accept ALBRECHT's (1982; 1983) proposal concerning the separation of groups within the Astacidae as a basic and valid idea as it is the first and up to now the only cladistic approach to European freshwater crayfish (SCHOLTZ, 2002). The genealogical tree proposed in the present paper is based on ALBRECHT's basic idea (Figure 1), but attempts to add three separate genus names to groups of species within the European Astacidae.

Based on the morphological criteria reported by ALBRECHT (1982; 1983), the number of postorbital ridges is not the same in $A$. torrentium and $A$. pallipes. In the latter species ALBRECHT $(1982 ; 1983)$ found remains of a second pair of postorbital ridges. A reduced second pair of postorbital ridges was finally used by ALBRECHT (1982) as a taxonomical feature for this clade. Like other above-mentioned authors, ALBRECHT (1982) described the smaller body size as another characteristic for this clade. Other criteria namely the tendency for a symmetrical formed tip of the pleopodite 1 of males and the shape of the rostrum are considered as not being clear and convincing (ALBRECHT, 1982). One morphological criterion for the sister group of $A$. pachypus and $A$. leptodactylus is the loss of ridges on the epistome (spines partially present). ALBRECHT (1982) correctly connected polyploidy only to the species $A$. leptodactylus. A. pachypus is distinguished 


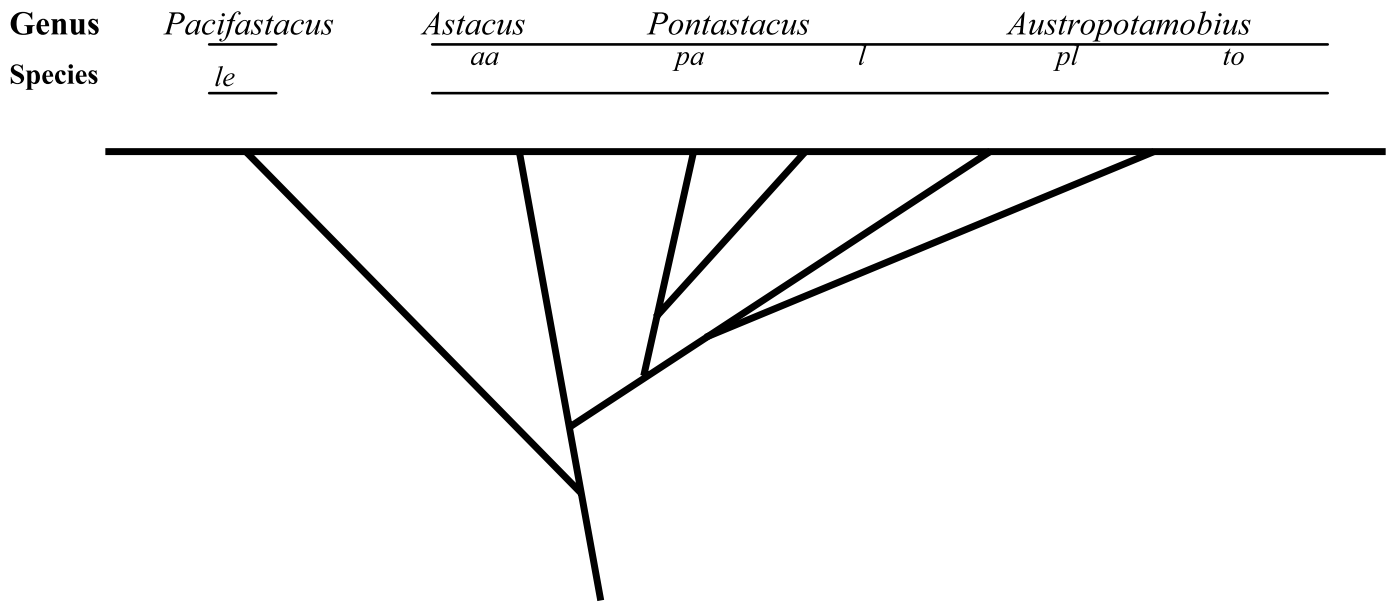

Figure 1

Proposal for a taxonomic classification of the crayfish species within the family Astacidae based on a tree modified from ALBRECHT (1982). Pontastacus is considered as a separate genus. Only those species are considered here, which had been included also in the original proposal by ALBRECHT (1982). The abbreviations used in the figure follow the original scheme used by ALBRECHT (aa - A. astacus, pa - A. pachypus, I - A. leptodactylus, to - A. torrentium, pl - A. pallipes, le $-P$. leniusculus).

Figure 1

Proposition de classification taxonomique des espèces d'écrevisses de la famille des astacidés, basée sur un arbre modifié d'après ALBRECHT (1982). Pontastacus est considéré comme un gène à part. Seules sont prises en considération ici les espèces qui sont incluses dans l'original proposé par ALBRECHT (1982). Les abréviations utilisées ici correspondent celles proposées par ALBRECHT (aa - A. astacus, pa - A. pachypus, I - A. leptodactylus, to - A. torrentium, $\mathrm{pl}-A$. pallipes, le $-P$. leniusculus).

by its strong chelae. From the origin of samples used by ALBRECHT (1982) it becomes obvious that eastern Europe (i.e. the Ponto-Caspian region) was not included in his analysis. Therefore his research cannot be judged as widely applicable, which was already admitted by ALBRECHT (1982) himself.

On the basis of ALBRECHT's (1982) concept of a genealogical tree, three separate groups can be identified within the European Astacidae: 1. Astacus astacus, 2. Astacus pachypus and Astacus leptodactylus, 3. Astacus pallipes and Astacus torrentium. A rather small number of species and the restriction to one genus seem to be the reasons why ALBRECHT's $(1982,1983)$ taxonomy was largely ignored by astacologists at least in terms of the terminology. In fact, his taxonomy is poorly reflected in scientific studies on European crayfish. The use of species names, such as Astacus pallipes and Astacus torrentium is relatively rare in recent literature, as a consequence of the more popular classification of these species as Austropotamobius pallipes and Austropotamobius torrentium.

In contrast to ALBRECHT's proposal, the taxonomy of STAROBOGATOV (1995) mentions a large number of genera (5) and species (19) within the European Astacidae crayfish. STAROBOGATOV (1995) raises subgenera of the genus Austropotamobius 
reported by BOTT (1950, 1972), and BRODSKI (1983) to the genera Atlantoastacus and Austropotamobius. As common morphological criteria he assumed a lack of the second pair of postorbital ridges (rejected by ALBRECHT (1982)) and the proportion of the rostrum shape. Criteria reported by ALBRECHT (1982) for A. pallipes were assumed by STAROBOGATOV (1995) as features for Atlantoastacus and in analogy to that, criteria for $A$. torrentium as features for the genus Austropotamobius. However, a lack of a talon in pleopod 2 of males for genus Austropotamobius as described by STAROBOGATOV (1995) is not always correct according to ALBRECHT (1982) (there can be a small one) and KARAMAN (1962) (big variation in talon size).

The part of the work of STAROBOGATOV (1995) concerning East European crayfish seemed to be mainly summarizing the taxonomical examinations of BIRSTEIN and WINOGRADOW (1934) and BRODSKI (1981) as well as his own revisions based on the extensive materials available at the Zoological Institute of the Russian Academy of Sciences at St. Petersburg and at the Zoological Institute of the Moscow State University. In contrast to West European taxonomists such as BOTT (1972), KARAMAN $(1962 ; 1963)$ or ALBRECHT (1982), STAROBOGATOV (1995) had access to a larger number of samples of the Astacus (Pontastacus) leptodactylus complex from eastern European territory.

According to STAROBOGATOV (1995), the genera Caspiastacus including the species Caspiastacus pachypus (Astacus pachypus by ALBRECHT (1982)) differs from Pontastacus mostly by the shape of the chelae but has a similar rostrum shape. The most important criteria commonly used to separate the two genera Astacus and Pontastacus are the pleura of the abdominal somites with 2-4 acute spines and the talon in pleopod 2 of males. Astacus has pleura of abdominal somites 2-4, which are wedge-shaped or rounded without spinules at the ventral ends (only the pleura of somite 4 may hold a hardly visible spinule in Astacus balcanicus) and the pleopod 2 of males without talon.

Soon after STAROBOGATOV (1995) published his taxonomic proposals, concerns were raised by other researchers. Critical comments mainly focused on the systematics of groups of crayfish, which were described by STAROBOGATOV (1995) without study or only based on weak examinations of the collected specimens. FITZPATRICK (1996) strongly suggested rejecting STAROBOGATOV's (1995) evaluations on Cambaridae and Parastacidae. However, the most important part of STAROBOGATOV's (1995) paper, specifically under the consideration of the origin of his samples, is related to the eastern Eurasian Astacidae. These were described and classified by him as belonging to the genera Pontastacus and Caspiastacus. These conclusions were raised on the basis of detailed analysis of museum collections and they were the result of work undertaken by such outstanding East European taxonomists as BIRSTEIN and WINOGRADOV (1934), and BRODSKI (1981). FITZPATRICK (1996) also agreed that these classifications of STAROBOGATOV (1995) are more likely to be acceptable. Since its publication, the proposals of STAROBOGATOV (1995) on the Astacus leptodactylus complex were not even commented upon, although this part of his work seems to be best documented.

STAROBOGATOV's (1995) proposal has been already partially revised based on genetic examinations of the genus Austropotamobius largely occurring in Western Europe, by GRANDJEAN et al. (2002), and indirectly by FRATINI et al. (2005), ZACCARA et al. (2005) and TRONTELJ et al. (2005). This work did not confirm his nomenclature of the species but seems to confirm his findings with regard to species variety. However, an even larger variety of species can be expected within the eastern European crayfish. Possible polyploidy and larger morphological variations in narrow-clawed crayfish compared to noble crayfish support this hypothesis. As a result, a high number of species and subspecies within the genus Pontastacus (BRODSKI, 1981; 1983; STAROBOGATOV, 1995) and similarly for the proposed genus Caspiastacus (STAROBOGATOV, 1995) cannot be neglected. 
The recently most widely used taxonomy was summarized by TAYLOR (2002). It recognizes five species (three species of Astacus and two species of Austropotamobius) in Europe and western Asia. This taxonomy is in fact very similar to those reported by ALBRECHT, only differing in the separation of the sister species group $A$. torrentium and $A$. pallipes into the genus Austropotamobius (see also Figure 1). The significance of this separation is further supported by recent genetic approaches that identified new species as for example Austropotamobius italicus (see GRANDJEAN, 2000) or a yet not named crayfish taxon, preliminarily still ranked within $A$. torrentium (see TRONTELJ et al., 2005).

\section{Pontastacus as a genus within the Astacidae}

In our opinion an additional change should be made towards the clarification of the European crayfish nomenclature. We propose to separate the genus Pontastacus containing for the time being two species: Pontastacus pachypus and Pontastacus leptodactylus. This proposal is based on results obtained using the criteria reported by the authors mentioned before. We consider the basic grouping of species within the European Astacidae as suggested by ALBRECHT (1982; 1983) fundamental. The subsequent separation of a genus Austropotamobius justifies, as a consequence, the introduction of a genus Pontastacus. The species Austropotamobius pallipes and Austropotamobius torrentium form one sister group similar to Pontastacus pachypus and Pontastacus leptodactylus as shown in Figure 1. The most important morphological criterion for the genus Austropotamobius is the lack of a second pair of postorbital ridges or at least a strong reduction. Pontastacus is characterized by two pairs of postorbital ridges and the pleura of the abdominal somites 2-4 with one or two acute spines. Astacus shows two pairs of postorbital ridges and the pleura of the abdominal somites 2-4 are wedge-shaped or rounded without spinules at the ventral ends (only the pleura of somite 4 can hold a hardly visible spinule).

It is, however, important to note that we observed many exceptions from the above-mentioned rules through our morphological studies on the narrow-clawed crayfish, which are likely to be the result of the large within-species variations, which we are only now beginning to understand. For example, at the genus Austropotamobius the lack of a second pair of postorbitals would be a good feature on the genus level, but such a second pair can be observed (at least in a reduced fashion) in Austropotamobius pallipes from some populations from e.g. new Yugoslavia (Serbia) (MACHINO, pers. comm.). A similar situation exists in the genus Pontastacus, where the criterion of the pleura of the abdominal somites 2-4 with one or two acute spines has its exception in Astacus astacus balcanicus KARAMAN (1963). This subspecies has differently developed (not acute) but still visible rudimental spines at the distal part of the abdominal somites. A similar situation exists with regard to the typical shape of the chelae (the exception is Astacus (Pontastacus) cubanicus) or the typical spiny carapace (the exception is Astacus (Pontastacus) eichwaldi).

It can be concluded that up to now there are no strong morphological features clearly separating the genera Astacus from Austropotamobis as well as Astacus from Pontastacus. Even the above-mentioned exceptions from the rather general rules, which also exist for the comparison of Astacus and Austropotamobius, do not provide strong evidence against a separation of Pontastacus as a genus or considering a single genus Astacus in the European Astacidae. Between these genera exists a phenomenon in terms of morphological features, which can be expressed as a margin of overlap. This general situation leads to the fact that it appears easier to separate species by defined morphological features than to describe genera based on widely applicable and typical morphological features. 
Apart from morphological criteria, the suggested modification in the taxonomy can be supported by the "original" zoogeographical distribution, which is a reflection of the phylogeny (excluding anthropogenic impacts due to transport and introductions of crayfish). There are a number of theories on the phylogeny of European Astacidae concluding that the origin and the subsequent dispersal of crayfish in Europe is an extremely complicated matter. Following the classic opinion on European crayfish phylogeny, the oldest Cretaceous crayfish in Europe were close to what we call Austropotamobius today and possibly belonged to the same genus (BOTT, 1950). If we further assume that Astacidae is a monophyletic group, which is again not generally accepted (SCHOLTZ, 2002), Astacus probably originated from Austropotamobius as discussed by STAROBOGATOV 1995 and dispersed over Europe and subsequently Pontastacus is probably derived from Astacus and thus forms the youngest group of crayfish in Europe. This rather generally summarized phylogeny disagrees with ALBRECHT's (1982) proposal but may be the reason for the patterns of natural distribution of Astacidae in Europe as we observe it today and as it is outlined below.

The distribution of Austropotamobius up to the western and southwestern "margins" of Europe shows the largest distance from the Ponto-Caspian region and the largest differences in terms of altitude. The distribution of Pontastacus is on the other hand still most closely refined to the Ponto-Caspian region and the genus Astacus can be regarded as an intermediate with respect to its geographical distribution. Furthermore, these assumptions seem to be supported by autecological requirements of the species within each genus. The genera Austropotamobius, Astacus and Pontastacus show an increasing tolerance with respect to general habitat and water quality parameters. This may be explained as a result of an adaptation to the process of eutrophication as it is related with the natural succession of standing waters (STAROBOGATOV, 1995).

Thus taking under consideration morphological and zoogeographical features and the ecological requirements of the species, we can divide the European Astacidae into the three groups Austropotamobius, Astacus and Pontastacus. Finally our proposal of taxonomy within the Astacidae is:

Family Astacidae Latreille, 1802-03

Genus Astacus Fabricius, 1775

Genus Pontastacus Bott, 1950

Genus Austropotamobius Skorikov, 1908

Genus Pacifastacus Bott, 1950

The number of species within the genus Pontastacus and the possible separation into the genera Pontastacus and Caspiastacus or a separation of Austropotamobius into Austropotamobius and Atlantoastacus is still a matter for further discussions. For the time being, we believe that the separation of three European Astacidae genera is justifiable. The studies recently undertaken on species belonging to the genus Austropotamobius are leading the way to seek further clarification on the taxonomy of European crayfish (for further discussion see TRONTELJ et al. (2005) and ZACCARA et al. (2005)).

Only a combination of morphological and molecular methods (e.g. BRODSKI et al., 1975; ROMANOV et al., 1976; AGERBERG, 1990; GRANDJEAN et al., 2000; 2002; SCHULZ et al., 2004; TRONTELJ et al., 2005) can finally help in this respect. Further studies on East European crayfish employing these modern approaches seem to be specifically needed, which is unfortunately not reflected in the work currently underway. 


\section{CONCLUSIONS}

Since there is an enormous morphological variation present especially in eastern European crayfish belonging to the Astacus (Pontastacus) leptodactylus complex, it appears to be very helpful to combine taxonomic research focusing on morphological features with the zoogeographical distribution and studies employing molecular techniques. Further studies with a focus on the eastern European species are essentially required.

\section{ACKNOWLEDGEMENTS}

We would like to thank an anonymous reviewer for valuable comments on an earlier draft of the manuscript. Our warmest thanks to Julian Reynolds, Catherine Souty-Grosset and Mikloš Puky for encouragement and valuable help.

\section{REFERENCES}

AGERBERG A., 1990. Genetic variation in three species of freshwater crayfish Astacus astacus L., Astacus leptodactylus Esch., and Pacifastacus leniusculus (Dana), revealed by isozyme electrophoresis. Hereditas, 113 (2), 101-108.

ALBRECHT H., 1982. Das System der europäischen Flusskrebse (Decapoda, Astacidae): Vorschlag und Begründung. Mitteilungen aus dem Hamburgischen Zoologischen Museum und Institut, 79, 187-210.

ALBRECHT H., 1983. Besiedlungsgeschichte und ursprüngliche holozäne Verbreitung der europäischen Flusskrebse (Decapoda: Astacidae). Spixiana, 6, 61-77.

ALBRECHT H., VON HAGEN H.O., 1981. Differential weighting of electrophoretic data in crayfish and fiddler crabs (Decapoda: Astacidae and Ocypodidae). Comparative Biochemistry and Physiology, 70B, 393-399.

BELYAEVA V., CHERKASHINA N.Ya., 1998. The state of populations of Astacus leptodactylus cubanicus in the waterbodies of the lower Don. 12 International Symposium of IAA, Augsburg - Proceedings (unpublished abstract).

BIRSTEIN Ya.A., WINOGRADOV L.G., 1934. Freshwater Decapoda of USSR and their geographical distribution. Zoologichesky Zhurnal., 13 (1), 39-70 (In Russian with English summary).

BOTT R., 1950. Die Flusskrebse Europas (Decapoda, Astacidae). Abhandlungen der Senckenbergischen Naturforschenden Gesellschaft, 483, 1-36.

BOTT R., 1972. Besiedlungsgeschichte und Systematik der Astaciden West-Europas unter besonderer Berücksichtigung der Schweiz. Revue Suisse de Zoologie, 79, 397-408.

BRODSKI S.Y., 1981. Richkovi raki. Fauna Ukrainy, 26 (3), 211 p. Naukova Dumka, Kiev. (In Ukrainian).

BRODSKI S.Y., 1983. On the systematics of palaearctic crayfishes (Crustacea, Astacidae). Freshwater Crayfish, 5, 464-469.

BRODSKI S.Y., BALAHININ I.A., ROMANOV L.M., 1975. Geneticheskij analiz populacionnoi strukturi rakov iz vodoiemov USSR. Elektricheskoie issledovanie sivorotochnih komponentov ghiemolimfy dlinnopalnovo raka. Genetika, 11 (4), 63-69. (In Russian).

CHERKASHINA N.Ya., BELYAEVA V., KARPENKO V., TEVYASHOVA O., GLUSHKO E., POROSHINA E., 1999. The state of populations of Pontastacus cubanicus (Birstein and Winogradow, 1934) in the water bodies of the lower Don (Russia). Freshwater Crayfish, 12, 643-54. 
FITZPATRICK J., 1996. Eurasian crayfish taxonomy revised - paper review. Crayfish News, 19 (1), 5-7.

FRATINI S., ZACCARA S., BARBARESI S., GRANDJEAN F., SOUTY-GROSSET C., CROSA G., GHERARDI F., 2005. Phylogeography of the threatened crayfish (genus Austropotamobius) in Italy: implications for its taxonomy and conservation. Heredity, 94, 108-118.

GRANDJEAN F., FRELON-RAIMOND M., SOUTY-GROSSET C., 2002. Compilation of molecular data for the phylogeny of the genus Austropotamobius: one species or several? Bull. Fr. Pêche Piscic., 367, 671-680.

GRANDJEAN F., HARRIS D.J., SOUTY-GROSET C, CRANDALL K.A., 2000. Systematics of the European endangered crayfish species Austropotamobius pallipes (Decapoda: Astacidae). Journal of Crustacean Biology, 20, 522-529.

HOLDICH D.M., 1992 Crayfish nomenclature and terminology: recommendations for uniformity. Finnish Fisheries Research, 14, 149-55.

HOLDICH D.M., GHERARDI F., 1999. Native and alien crayfish in Europe: an introduction. In: F. GHERARDI \& D.M. HOLDICH (eds.), Crayfish in Europe as alien species: How to make the best of a bad situation, Balkema, Rotterdam, 3-9.

KARAMAN M.S., 1962. Ein Beitrag zur Systematik der Astacidae (Decapoda). Crustaceana, 3, 173-191.

KARAMAN M.S., 1963. Studie der Astacidae (Crustacea, Decapoda). II Teil. Hydrobiologia, $22,111-132$

LARGIADÈR C.R., HERGER F., LÖRTSCHER M., SCHOLL A., 2000. Assessment of natural and artificial propagation of the white-clawed crayfish Austropotamobius pallipes species complex) in the Alpine region with nuclear and mitochondrial markers. Molecular Ecology, 9, 25-37

MASTYŃSKI J., ANDRZEJEWSKI W., 2001 a. Cechy morfometryczne i rozpoznawanie raków występujących w Polsce. Wydawnictwo Akademii Rolniczej im. A. Cieszkowskiego, Poznań, 7-29 (in Polish).

MASTYŃSKI J., ANDRZEJEWSKI W., 2001 b. Populations of crayfish in Polish waters of west Poland with particular consideration of the noble crayfish (Astacus astacus L.). Animal Science, Scientific Papers of Agricultural University of Poznań, 3, 5-14.

MIKOUIZA A.-S., SOKOLSKY A., USHIVTSEV V., KOLMIKOV E., 1998. Biogeography of crayfish populations (Crustacea, Decapoda, Astacidae) in the Volga-Caspian region. 12 International Symposium of IAA, Augsburg - Proceedings (unpublished abstract).

PROWAZEK S., 1902. Ein Beitrag zur Krebsspermatogenese. Zeitschrift für Wissenschaftliche Zoologie, 71, 445-56.

ROMANOV L.M., BALAKHININ I.A., BRODSKI S.Y., 1976. Geneticheskij analiz populacionnoi strukturi rakov iz vodoiemov USSR. Genetika, 12, 81-85. (In Russian).

SCHOLTZ G., 2002. Phylogeny and Evolution. In: D.M. HOLDICH (ed.), Biolology of Freshwater Crayfish. Blackwell Science, 30-52 + pl. 10-16.

SCHULZ H.K., ŚMIETANA P., SCHULZ R., 2004. Assessment of DNA variations of the noble crayfish (Astacus astacus L.) in Germany and Poland using Inter-Sample Sequence Repeats (ISSRs) Bull. Fr. Pêche Piscic., 372-373, 387-399. 
SILVER D., CUKERZIS J.M., 1964. Chislo khromosomov dlinnopalnovo raka Astacus leptodactylus. Tsitologiya, 6, 631-633. (In Russian with English summary).

ŚMIETANA P., 1998. Występowanie raków rodzimych w Polsce północno-zachodniej i analiza porównawcza cech ich populacji, ze szczególnym uwzględnieniem raka błotnego (Pontastacus leptodactylus Eschscholtz, 1823). PhD - dissertation. Agricultural University of Szczecin, 1-128 (in Polish).

ŚMIETANA P., 1999. Nasze raki. Rak blotny (Pontastacus leptodactylus Esch). Przegląd Rybacki, 2, 8-12. (In Polish).

ŚMIETANA P., 2001. On the distribution of narrow-clawed crayfish (Astacus leptodactylus Esch.) in Western Poland. Animal Science, Scientific Papers of Agricultural University of Poznań, 3, 25-33.

SOKOLSKY A., USHIVTSEV V., MIKOUIZA A.-S., KALMIKOV E., 1999. Influence of sea level fluctuations on wild crayfish populations in the Caspian Sea. Freshwater Crayfish, 12, 655-664.

STAROBOGATOV Y.I., 1995. Taxonomy and geographical distribution of crayfishes of Asia and East Europe (Crustacea, Decapoda, Astacoidei). Arthropoda Selecta, 4 (3/4), 3-25.

TAYLOR C.A., 2002. Taxonomy and conservation of native crayfish stocks. In: D.M. HOLDICH (ed.), Biolology of Freshwater Crayfish. Blackwell Science, 236$257+$ pl. 24-27.

TRONTELJ P., MACHINO Y., SKET B., 2005. Phylogenetic and phylogeographic relationships in the crayfish genus Austropotamobius inferred from mitochondrial COI gene sequences. Molecular Phylogenetics and Evolution, 34, 212-226.

ZACCARA S., STEFANI F., CROSA G., 2005. Diversity of mitochondrial DNA of the endangered white-clawed crayfish (Austropotamobius italicus) in the Po River catchment. Freshwater Biology, 50, 1262-1272. 